\title{
Micromorph and polymorphous solar panel in a warm temperature transitional climate - comparison of outdoor performance and simulations
}

\author{
G. Lewinska ${ }^{1 *}$ K. Dynda ${ }^{1 *}$, J. Sanetra, K.W. Marszalek ${ }^{1}$ \\ ${ }^{1}$ AGH University of Science and Technology, Institute of Electronics \\ 30 Mickiewicza Ave., 30-059 Krakow ( Poland) Phone: +48 126175616 \\ e-mail: glewinska@agh.edu.pl, kkoper@agh.edu.pl, marszalek@agh.edu.pl \\ ${ }^{2}$ The author Jerzy Sanetra is retired. e-mail: pusanetr@cyf-kr.edu.pl
}

\begin{abstract}
The publication contains polymorphic and micromorphic photovoltaic module outdoor tests performed during autumn, winter, spring and summer day. Simulations of an installation consisting of panels both types have been made. Both performances were compared for the location in the KrakówCzęstochowa Upland, continental climate.
\end{abstract}

Key words. photovoltaic, power losses, outdoor performance, polycrystalline silicon module, micromorphous module

\section{Introduction}

Photovoltaics, as the fastest growing type of renewable energy, is continuously developed. Photovoltaics achievements are promising and new performance limits are constantly being crossed [1,2]. The first generation of photovoltaics is based on crystalline silicon. Silicon is the most popular material on the photovoltaic cell market (about $90 \%$ of commercialized cells are silicon). There are four types photovoltaic solar cells based on silicon: monocrystalline, polycrystalline, amorphous and hybrid silicon cells. More and more silicon based photovoltaic solar cells types are being developed [3-8]. The paper will present a comparison of the work of polycrystalline and micromorphic cells in the field conditions.

Polycrystalline silicon cells [9-11] are obtained by the controlled melting and re-coagulation of silicon in a quartz crucible. The waffle is cut from the block thus obtained, after which a number of processes are carried out, leading to the formation of the functional solar cell. The production of polycrystalline material for solar cells is cheaper then monocrystalline, because it needs less electrical energy and time. Micromorphic [12-14] cells are examples of tandem cells. They are a combination of microcrystalline silicon $(\mu \mathrm{c}-\mathrm{Si})$ and thin film amorphous technology (a-Si).
Photovoltaics needs increasingly precise methods of characterisation and measurement. Basic tests of the photovoltaic panels are usually carried out in the laboratories using Standard Test Conditions (STC) $[15,16]$. Measurement according to STC is a test at $1000 \mathrm{~W} / \mathrm{m}^{2}$ exposure at a cell temperature of $25^{\circ} \mathrm{C}$ and Air Mass radiation spectrum parameter - AM 1.5. The panel parameters may also be quoted using Normal Operating Cell Temperature (NOCT) $[17,18]$. These are the cell parameters obtained when temperature reached by open circuited cells in a module assuming $800 \mathrm{~W} / \mathrm{m}^{2}$ irradiance, $20^{\circ} \mathrm{C}$ ambient temperature and wind speed of $1 \mathrm{~m} / \mathrm{s}$ with the module at a tilt angle of $45^{\circ}$.

Both STC and NOCT conditions will never occur in practice. With practically insolation $1000 \mathrm{~W} / \mathrm{m}^{2}$ it is not possible to maintain the temperature of the cell at $25^{\circ} \mathrm{C}$ (with no external cooling [19,20]). Parameter AM 1.5 specifies that the sun's rays fall at an angle of $48,2^{\circ}$ to the position of the sun in the zenith. The intensity of sunlight and temperature are almost always different from those assumed in STC, as well as the tilt angle.

In order to confirm the long-term and actual behaviour of the cells and parameters, tests in the external environment are required. The different temperatures and weather conditions are able to give an idea of the actual performance and benefits of silicon photovoltaics. Therefore, it is interesting and research on real parameters in different climates is being conducted [21-26].

\section{Location and technical conditions}

A. Location and climatic condition

The measurements were carried out in the Education and Research Centre for Renewable Energy Sources and Energy Conservation at the AGH University of Science and Technology in Miękinia, Małopolskie Voivodship, Poland (50 09'37.7"N 19॰36'04.0"E). It is situated on the Kraków-Częstochowa Upland, within the 
Silesian-Cracowian monocline, and in the southern part in the area of the pre-Carpathian sinkhole.

The most appropriate feature for determining the climate of Poland is the transience of the climate, which is conditioned by the abrasion of air masses with different characteristics from several barium centres. The formation of air temperature clearly shows oceanic and continental influences. In January, the isotherms are arranged in a longitudinal direction, and in July - in a parallel direction. The weather shows variability and significant fluctuations of the seasons in successive years. This is caused by the borderline between a warm and rainy temperate climate and a boreal, snow-forest climate running through Poland. The annual isoamplitudes are about $20^{\circ} \mathrm{C}$ and $23^{\circ} \mathrm{C}$, which define the conventional boundaries between the oceanic and continental climate, also pass through. Intensity even on a sunny summer day rarely exceeds $900 \mathrm{~W} / \mathrm{m}^{2}$ in Poland.

\section{B. Modules technical description}

The photovoltaic installation consisting of photovoltaic modules of different generations placed on a metal rack structure (Figure 1). Two modules were selected for comparison in the work: the polymorphic module from German Solar (GSP6-S160 model) and micromorph module from Sontor (silicon tandem thin film solar module SN2-130).

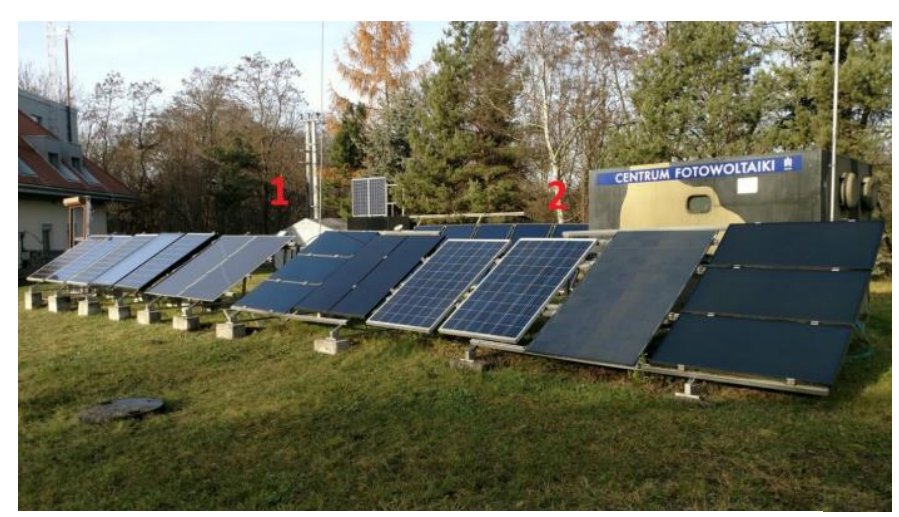

Figure 1. Location of panels on the frame (1) micromorphous (2) polymorphous

The basic solar cell parameters provided by the manufacturer are shown in Table 1. The following are listed: Pmax (maximum power point designated as MPP) maximum voltage $\left(\mathrm{V}_{\mathrm{m}}\right)$ and a current $\left(\mathrm{I}_{\mathrm{m}}\right)$, short circuit current $\left(\mathrm{I}_{\mathrm{sc}}\right)$ and the open-circuit voltage $\left(\mathrm{V}_{\mathrm{OC}}\right)$. Temperature coefficients given by the manufacturer were also taken into account. Both panels operate at a typical operating temperature range $-40 \sim 85^{\circ} \mathrm{C}$.

Table 1. Basic panel parameters measured in STC

\begin{tabular}{|c|c|c|}
\hline panel & $\begin{array}{l}\text { SN2-130.0, } \\
\text { Sontor, }\end{array}$ & $\begin{array}{l}\text { GSP6-240- } \\
\text { SI60, } \\
\text { German } \\
\text { Solar }\end{array}$ \\
\hline $\mathrm{P}_{\max }[\mathrm{W}]$ & 130 & 240 \\
\hline $\mathrm{I}_{\mathrm{m}}[\mathrm{A}]$ & 1.64 & 8.05 \\
\hline $\mathrm{U}_{\mathrm{m}}[\mathrm{V}]$ & 97.2 & 29.80 \\
\hline $\mathrm{I}_{\mathrm{sc}}[\mathrm{A}]$ & 1.62 & 8.56 \\
\hline $\mathrm{V}_{\mathrm{oc}}[\mathrm{V}]$ & 127.1 & 37.4 \\
\hline $\begin{array}{c}\text { temperature coefficient of } \\
\mathrm{P}_{\max }\left[\% /{ }^{\circ} \mathrm{C}\right]\end{array}$ & -0.44 & -0.40 \\
\hline $\begin{array}{c}\text { temperature coefficient of } \\
\mathrm{I}_{\mathrm{sc}}\left[\% /{ }^{\circ} \mathrm{C}\right]\end{array}$ & -0.334 & -0.39 \\
\hline $\begin{array}{c}\text { temperature coefficient of } \\
\mathrm{V}_{\mathrm{oc}}\left[\% /{ }^{\circ} \mathrm{C}\right]\end{array}$ & 0.069 & 0.07 \\
\hline
\end{tabular}

\section{Results}

\section{A. Measurements}

The measurements were taken during the day during the four seasons - autumn, winter and spring, summer. The measurements were taken from 2019 to 2020 (8th November - autumn, 20th February - winter, 21st April - spring and 18th July - summer). The ideal course of the characteristics during the day is a symmetrical parabola, half-width and maximum depending on the season. Temperature and humidity variations over the investigation days were presented in the Figure 2. The results are based on the data from publicly available meteorological stations [27].

The Figure 3. shows dependence of power generated by investigated panels during the day.
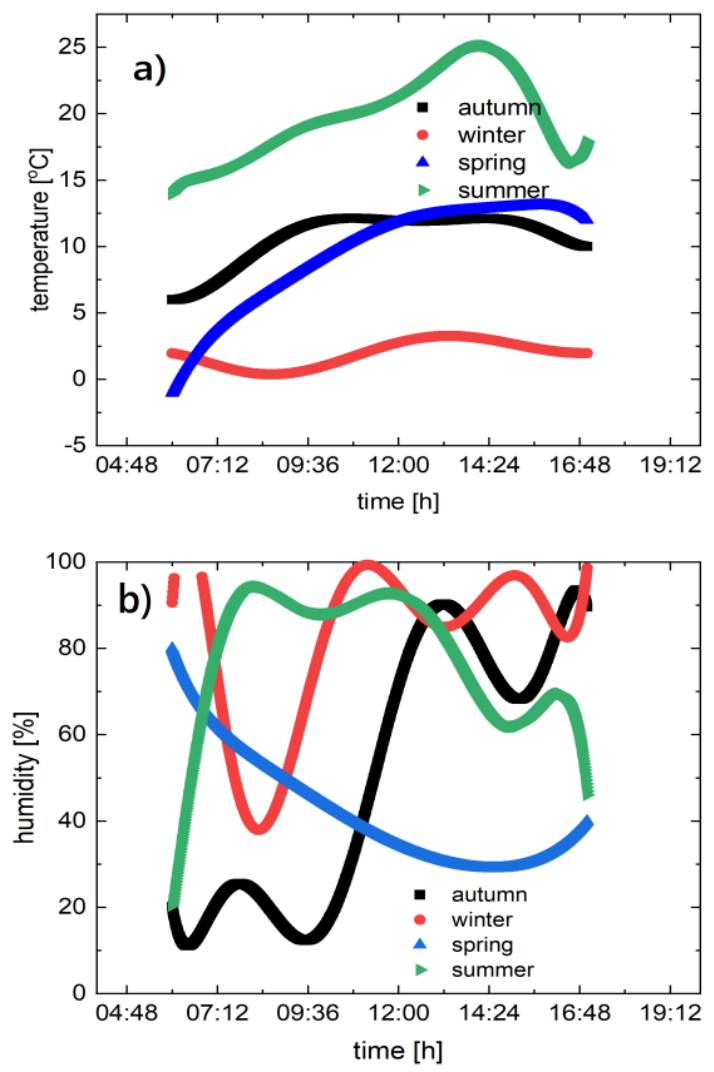

Figure 2. Temperature and humidity variations over the investigation days 

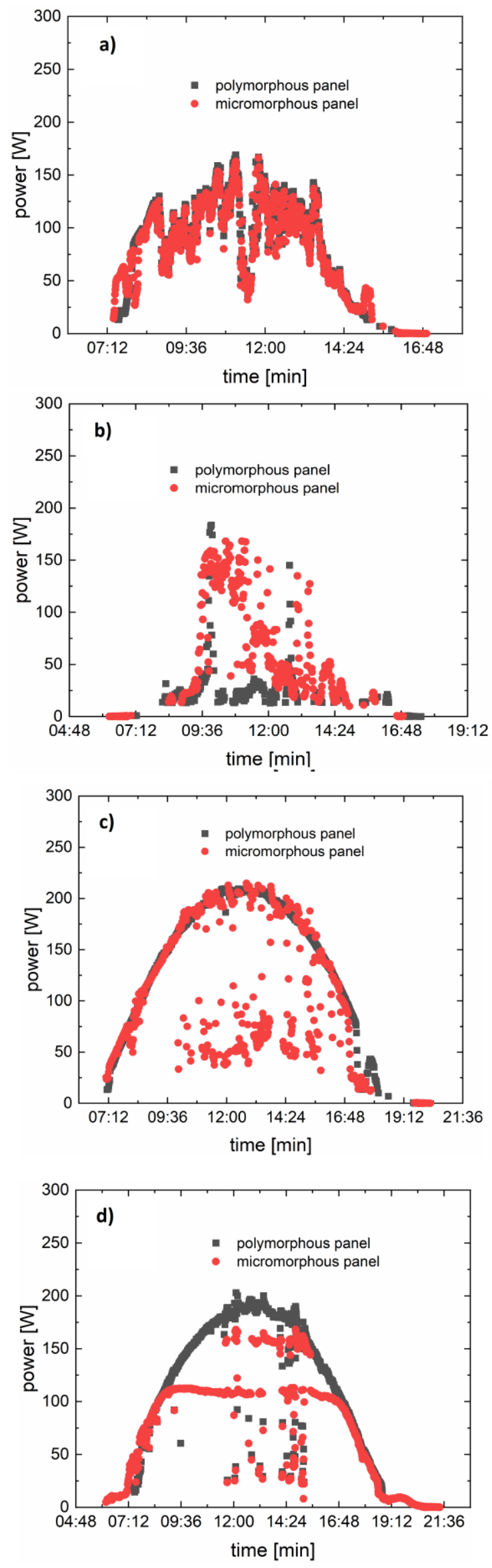

Figure 3. Daily characteristics of the panel power during the day a) autumn, b) winter c) spring d) summer The time colour means the waveforms for the polymorphic panel, red - micromorph
The most similar to the standard daily power output, are the spring and summer spectra. In winter and autumn, significant power fluctuations are observed. On the autumn day, during the highest temperature, the power was $150 \mathrm{~W}$, at $5.72^{\circ} \mathrm{C}$ average daily temperature. In winter the maximum power was $130 \mathrm{~W}$, with an average daily temperature of $1.56^{\circ} \mathrm{C}$. The spring day with an average temperature of $9.73^{\circ} \mathrm{C}$ showed a power of about $200 \mathrm{~W}$ for both modules. On summer day (average temperature $13.8^{\circ} \mathrm{C}$ ) the only difference between the panels appeared. Changes in input power are not correlated with either temperature or humidity. The daytime temperatures vary in a range that strongly depends on the season stabile, similarly there is no humidity dependence, also. However, we may hypothesize that the power output is strongly influenced by varying clouds.

Definitely higher power values are obtained in the summer day analysis. The power output signal on both cells is similar for both cells. Large changes in the drop in performance of the micromorphic panel are observed only on the spring day. These changes can only come from selective shading of the micromorphic panel. Around noon, you can see the increased power output the shading has almost disappeared. The average values of the power output in both cases do not generally fluctuate - despite the higher power point, the polymorphic cell in principle.

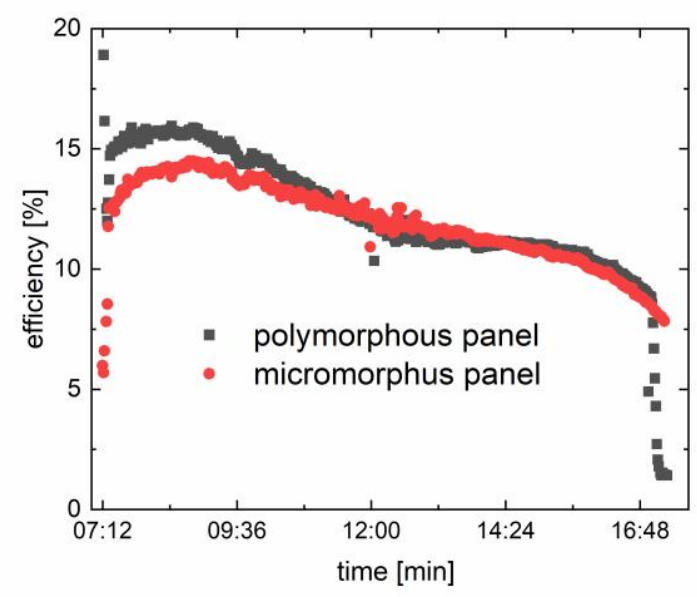

Figure 4. Efficiency comparison for panels during a daytime

\section{B. Simulations}

The Vela Solaris Polysun [28] is a popular software for the simulation of both photovoltaic and hybrid (e.g. thermovoltaic) installations. The inverter Sunrise Midi Plus was used. Using Polysun software simulation for a panel arrangement (consisting of ten panels of a selected type located in the location as reported) was carried out. The Figure 5 (micromorphous panels SN2-130.0, Sontor). and Figure 6 (polymorphous panel, GSP6-240-SI60, German Solar ) show the power generated by the installations with the average efficiency of the panel, with the weather conditions of the programme database shown in the Figure 7. 

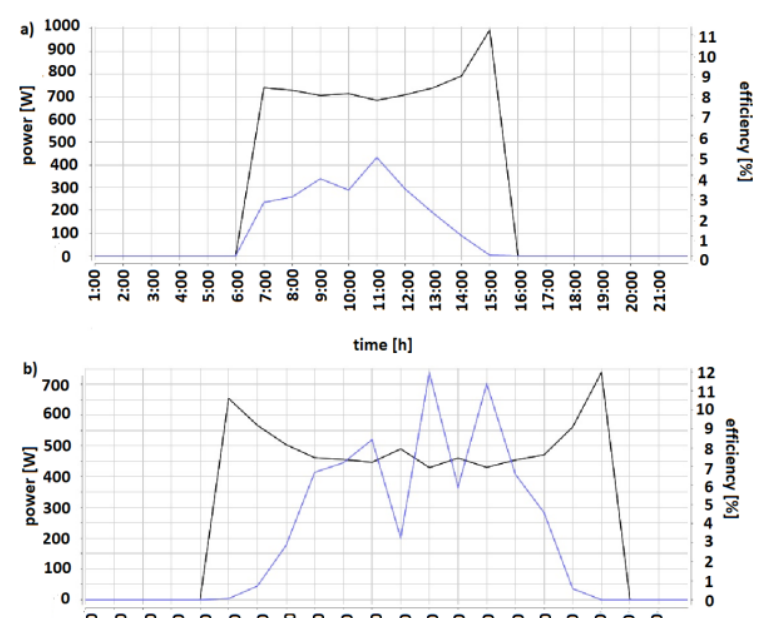

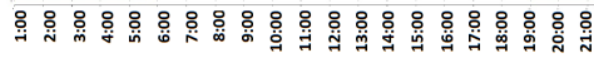

time [h]

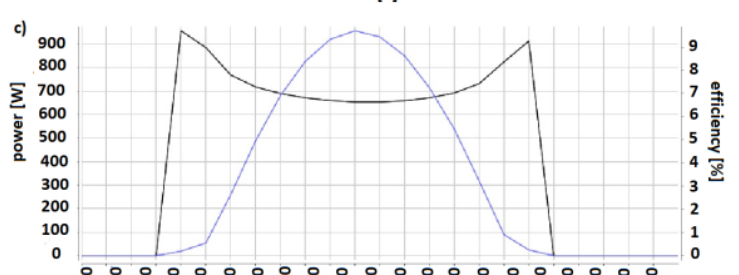

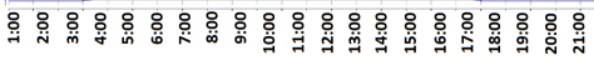

time [h]

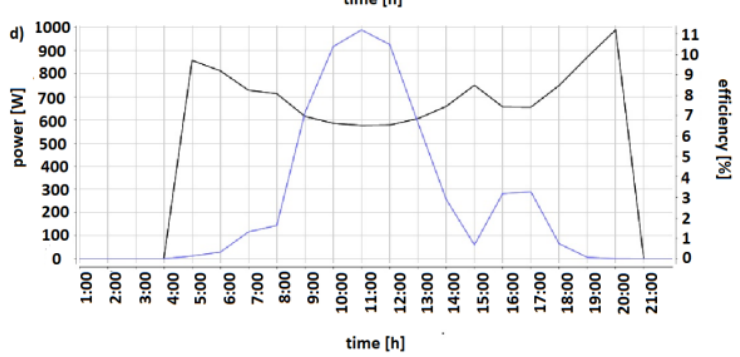

Figure 5. Daily characteristics of the panel power (black line) and efficiency (blue line) during the day a) autumn, b) winter c) spring d) summer for micromorph panels SN2-130.0, Sontor

The obtained curves have similar shape to the recorded results, however, significant differences can be seen in the continuity of the real performance. The comparison of the maximum performance received is shown in Table 2.

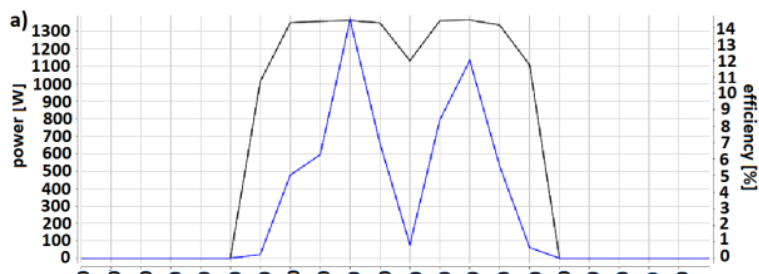

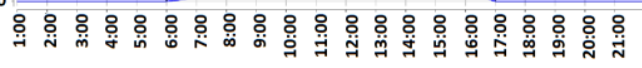
time [h]

b)
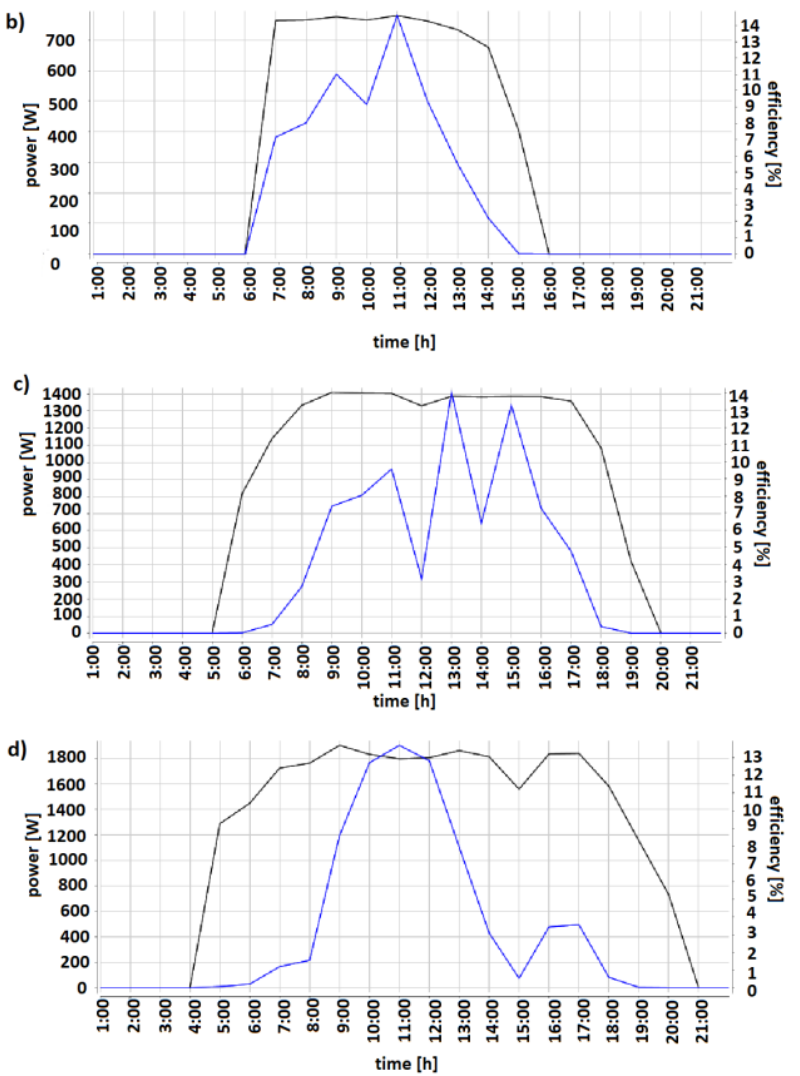

Figure 6. Daily characteristics of the panel power (black line) and efficiency (blue line) during the day a) autumn, b) winter c) spring d) summer for polymorphous panel, German Solar

Table 2. Maximum power generated. For the installation simulation it has been converted to 1 panel

\begin{tabular}{|c|c|c|c|c|}
\hline \multirow{2}{*}{$\begin{array}{c}\text { Power } \\
{[\mathrm{W}]}\end{array}$} & \multicolumn{2}{|c|}{ outdoor performance } & \multicolumn{2}{c|}{ simulations } \\
\cline { 2 - 5 } & $\begin{array}{c}\text { Micro- } \\
\text { morphous }\end{array}$ & $\begin{array}{c}\text { Poly- } \\
\text { morphous }\end{array}$ & $\begin{array}{c}\text { Micro- } \\
\text { morphous }\end{array}$ & $\begin{array}{c}\text { Poly- } \\
\text { morphous }\end{array}$ \\
\hline autumn & 150 & 150 & 100 & 130 \\
\hline winter & 150 & 150 & 75 & 80 \\
\hline spring & 200 & 200 & 100 & 140 \\
\hline summer & 100 & 200 & 100 & 180 \\
\hline
\end{tabular}



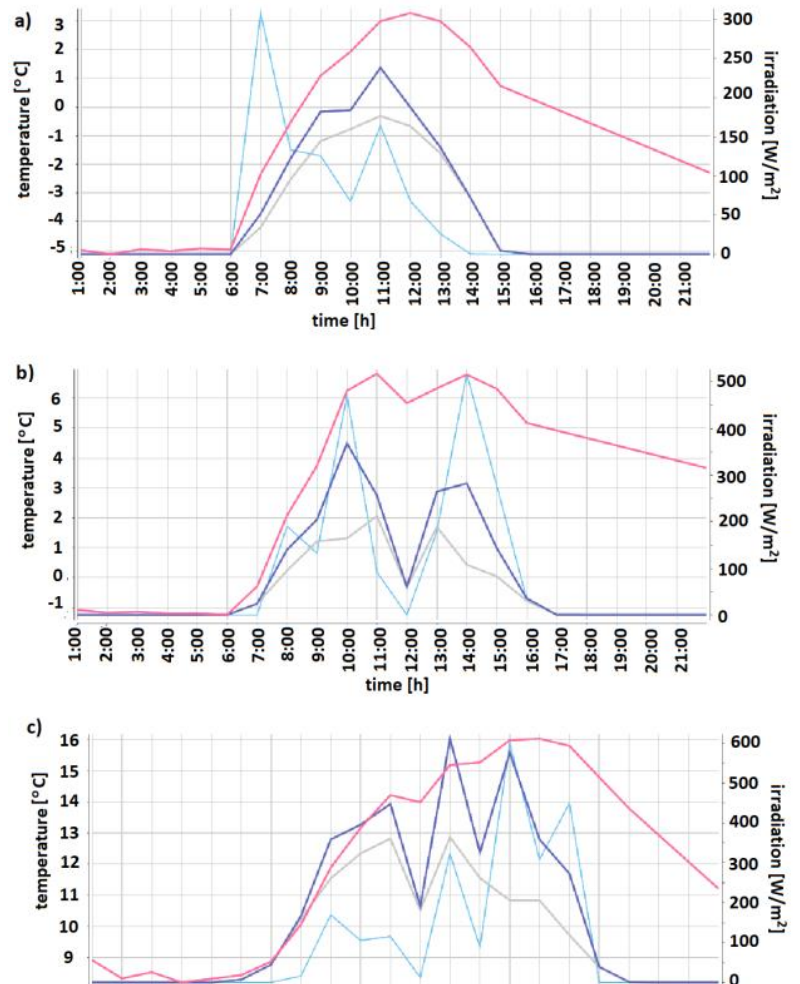

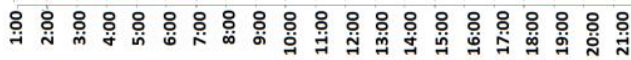
time [h]

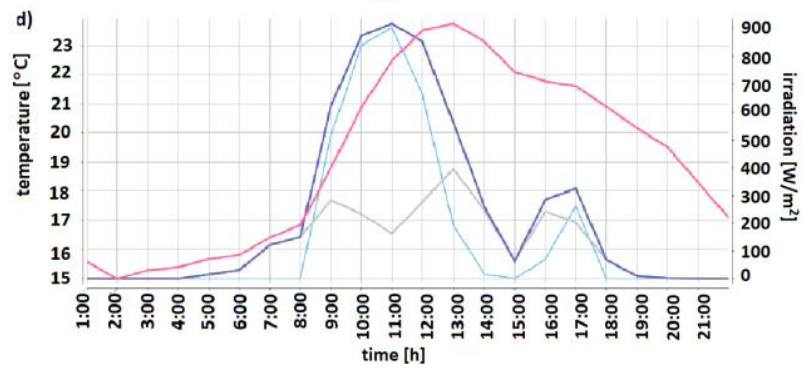

Figure 7. Daily characteristics of the temperature (red line) and global irradiation (blue line), diffuse irradiation (purple line) normal direct irradiation (grey line) during the day a) autumn, b) winter c) spring d) summer

The maximum power obtained in both ways of registration is strongly differentiated. This is particularly observed the winter. Maximum values higher than expected for the recorded outdoor performance values appear, which may be due to additional factors such as temporary cooling due to the atmospheric factors. The simulation values are based on catalogues so they are more stable data, however, their inadequacy must be considered.

\section{Conclusion}

The paper presents executive tests of panels in real conditions. The performance of photovoltaic installation was also simulated. The aim of the study was to determine the changes in efficiency during the year under sunshine conditions at different seasons of the year during the day. The waveforms and temperature profiles in the cells will be presented and compared with the simulations performed.

For the micromorphic cell, the actual (outdoor) values turned out to be more favourable than the values obtained by simulation with the Polysun program. The increase in maximum power achieved was twice as high in winter and spring, while in autumn the actual values were $50 \%$ higher. In summer, simulation and measurements showed the same value. In the case of the polymorphic panel also the maximum powers are higher for outdoor performance. In this case, the significant change is only in the spring season (about 30\%). In the other cases, the difference is 5-20\%. The powers measured for the panels have a very jumpy power delivery, their characteristics are jagged due to environmental influences. However, the disadvantages of outdoor operation are apparently compensated for. Both panels perform better than expected, confirming that photovoltaics is a promising and efficient renewable energy source for the future. The results also point to the need for intensified outdoor research, as well as the importance of obtaining better and better simulations models.

\section{Acknowledgement}

This research was funded by statutory project of Department of Electronics AGH University in Cracow.

\section{References}

[1] M. Einzinger, T. Wu, J.F. Kompalla, H.L. Smith, C.F. Perkinson, L. Nienhaus, S. Wieghold, D.N. Congreve, A. Kahn, M.G. Bawendi, M.A. Baldo, Sensitization of silicon by singlet exciton fission in tetracene, Nature. (2019) Vol. 571 pp. 90-94.

[2] L. Hernández-Callejo, S. Gallardo-Saavedra, V. Alonso-Gómez, A review of photovoltaic systems: Design, operation and maintenance Keywords: Design of photovoltaic systems Operation of photovoltaic systems Maintenance of photovoltaic systems, Sol. Energy. (2019) Vol 144 . pp. 426440.

[3] M. Stuckelberger, R. Biron, N. Wyrsch, F.J. Haug, C. Ballif, Review: Progress in solar cells from hydrogenated amorphous silicon, Renew. Sustain. Energy Rev. (2017) Vol. 76 pp. $1497-1523$.

[4] M.T. Zarmai, N.N. Ekere, C.F. Oduoza, E.H. Amalu, A review of interconnection technologies for improved crystalline silicon solar cell photovoltaic module assembly, Appl. Energy. (2015) VOl. 154 pp.173-182.

[5] L.L. Yan, C. Han, B. Shi, Y. Zhao, X.D. Zhang, A review on the crystalline silicon bottom cell for monolithic perovskite/silicon tandem solar cells, Mater. Today Nano. (2019) Vol. 7 pp. 100045.

[6] F. Meillaud, M. Boccard, G. Bugnon, M. Despeisse, S. Hänni, F.J. Haug, J. Persoz, J.W. Schüttauf, M. Stuckelberger, C. Ballif, Recent advances and remaining challenges in thin-film silicon photovoltaic technology, Mater. Today. (2015) Vol. 18 pp. 378-384.

[7] T. Ahmed, S. Mekhilef, R. Shah, N. Mithulananthan, An assessmenpp.t of the solar photovoltaic generation yield in Malaysia using satellite derived datasets, Int. Energy J. (2019) Vol. 1961-76.

[8] P. Yu, J. Wu, S. Liu, J. Xiong, C. Jagadish, Z.M. Wang, Design and fabrication of silicon nanowires towards efficient solar cells, Nano Today. (2016) Vol. 11 pp. 704-737.

[9] C.E.C. Nogueira, J. Bedin, R.K. Niedzialkoski, S.N.M. De Souza, J.C.M. Das Neves, Performance of monocrystalline and polycrystalline solar panels in a water 
pumping system in Brazil, Renew. Sustain. Energy Rev. (2015)Vol. 51 pp. 1610-1616.

[10] M.B. de la Mora, O. Amelines-Sarria, B.M. Monroy, C.D. Hernández-Pérez, J.E. Lugo, Materials for downconversion in solar cells: Perspectives and challenges, Sol. Energy Mater. Sol. Cells. (2017) Vol. 165 pp. 59-71.

[11] V. Suendo, F. Kail, P.R. Cabarrocas, S. Tchakarov, D. Das, O. Saadane, A. V Kharchenko, V. Suendo, F. Kail, P. Roca I Cabarrocas, Helium versus hydrogen dilution in the optimization of polymorphous silicon solar cells, Artic. J. NonCrystalline Solids. (2004).

[12] D. Fischer, S. Dubail, J.A. Anna Selvan, N. Pellaton Vaucher, R. Platz, C. Hof, U. Kroll, J. Meier, P. Torres, H. Keppner, N. Wyrsch, M. Goetz, A. Shah, K.D. Ufert, "Micromorph" solar cell: extending a-Si:H technology towards thin film crystalline silicon, in: Conf. Rec. IEEE Photovolt. Spec. Conf., IEEE, 1996: pp. 1053-1056.

[13] A. Shah, J. Meier, E. Vallat-Sauvain, C. Droz, U. Kroll, N. Wyrsch, J. Guillet, U. Graf, Microcrystalline silicon and "micromorph" tandem solar cells, Thin Solid Films. (2002)

Vol. 403-404, pp.179-187

[14] J. Fang, L. Bai, T. Li, G. Hou, B.Z. Li, C. Wei, G. Wang, D. Zhang, Y. Zhao, X. Zhang, High-efficiency micromorph solar cell with light management in tunnel recombination junction, Sol. Energy Mater. Sol. Cells. 155 (2016) Vol .155 pp. 469-473.

[15] M. Nethra, B. Kalidasan, Earth tube heat exchanger design for efficiency enhancement of PV panel, Mater. Today Proc. (2020) pp. 1-5.

[16] M.A. Muñoz-García, O. Marin, M.C. Alonso-García, F. Chenlo, Characterization of thin film PV modules under standard test conditions: Results of indoor and outdoor measurements and the effects of sunlight exposure, Sol. Energy. (2012) Vol. 86 pp. 3049-3056.

[17] G. Osma-Pinto, G. Ordóñez-Plata, Dynamic thermal modelling for the prediction of the operating temperature of a PV panel with an integrated cooling system, Renew. Energy. (2020) Vol 152 pp. 1041-1054.

[18] C. Toledo, R. López-Vicente, J. Abad, A. Urbina, Thermal performance of PV modules as building elements: Analysis under real operating conditions of different technologies., Energy Build. (2020) Vol. 22 3pp. 110087.

[19] M.B. Elsheniti, M.A. Hemedah, M.M. Sorour, W.M. El-Maghlany, Novel enhanced conduction model for predicting performance of a PV panel cooled by PCM, Energy Convers. Manag. (2020) Vol. 205 pp. 112456.

[20] F. Bayrak, H.F. Oztop, F. Selimefendigil, Experimental study for the application of different cooling techniques in photovoltaic (PV) panels, Energy Convers. Manag. (2020) Vol. 212 pp. 112789.

[21] N.A.S. Elminshawy, A.M.I. Mohamed, K. Morad, Y. Elhenawy, A.A. Alrobaian, Performance of PV panel coupled with geothermal air cooling system subjected to hot climatic, Appl. Therm. Eng. (2019) Vol. 148 pp. 1-9.

[22] G. Osma-Pinto, G. Ordóñez-Plata, Measuring factors influencing performance of rooftop PV panels in warm tropical climates, Sol. Energy. (2019) Vol. 185 pp. 112-123.

[23] G.A. Thopil, C.E. Sachse, J. Lalk, M.S. Thopil, Techno-economic performance comparison of crystalline and thin film PV panels under varying meteorological conditions: A high solar resource southern hemisphere case, Appl. Energy. (2020) Vol. 275 pp. 115041.

[24] A. Guenounou, A. Malek, M. Aillerie, Comparative performance of $\mathrm{PV}$ panels of different technologies over one year of exposure: Application to a coastal Mediterranean region of Algeria, Energy Convers. Manag. (2016) Vol. 114 pp. 356-363.

[25] S.S. Korsavi, Z.S. Zomorodian, M. Tahsildoost, Energy and economic performance of rooftop PV panels in the hot and dry climate of Iran, J. Clean. Prod. (2018) Vol. 174 pp.12041214.
[26] P. Viebahn, O. Soukup, S. Samadi, J. Teubler, K. Wiesen, M. Ritthoff, Assessing the need for critical minerals to shift the German energy system towards a high proportion of renewables, (2015) Vol. 49 pp 655-671.

[27] Index of /data/dane_pomiarowo_obserwacyjne/dane_meteorologiczne, (n.d.). https://dane.imgw.pl/data/dane_pomiarowo_obserwacyjne/dane _meteorologiczne/ (accessed October 15, 2020).

[28] Vela Solaris, Polysun - Simulation Software for Energy Systems, POLYSUN, (n.d.). https://www.velasolaris.com/software/?lang=en (accessed November 19, 2020). 